\title{
Special issue "2016 Kumamoto earthquake sequence and its impact on earthquake science and hazard assessment"
}

\author{
Manabu Hashimoto ${ }^{1 *}$, Martha Savage ${ }^{2}$,Takuya Nishimura ${ }^{1}$, Haruo Horikawa ${ }^{3}$ and Hiroyuki Tsutsumi ${ }^{4}$
}

The Kumamoto earthquake sequence that started on April 15, 2016, resulted in more than 60 fatalities and brought about serious damage to Kumamoto Prefecture. It is the first time that the seismic intensity of 7 (on the Japan Meteorological Agency scale) was recorded twice within 2 days, which unnerved the population in the affected areas and made the response difficult. Furthermore, seismicity spread out across Kyushu Island, which enhanced uneasiness in society. The earthquakes occurred on known active faults where long-term probability of earthquake occurrence was disseminated, but such complex activity was unexpected. This unique sequence will clearly have a significant impact on the field of earthquake science and related hazard assessment.

This special issue is a compilation of 43 papers on multidisciplinary research regarding this unique sequence, the relevant tectonics and associated phenomena with state-of-the-art techniques as well as traditional ones.

Many papers discuss source processes based on studies from the viewpoint of their own discipline, such as teleseismic seismograms, strong ground motion records and surface displacements detected by space geodesy. Yagi et al. (2016) reveal the temporal evolution of rupture using seismograms from a global network. In contrast, Asano and Iwata (2016), Kubo et al. (2016), Nozu and Nagasaka (2017) and Yoshida et al. (2017) discuss the detailed rupture process using strong ground motion records. Their modeled faults have significant differences among them in the number of faults and geometry, but similar characteristics in slip distribution and temporal evolution of rupture are derived. Nozu and Nagasaka (2017) assume a single planar fault, while Kubo et al. (2016) use a single, smoothly curved plane. Asano and

\footnotetext{
*Correspondence: hashimoto.manabu.7e@kyoto-u.ac.jp

1 Disaster Prevention Research Institute, Kyoto University, Uji 611-0011, Kyoto, Japan

Full list of author information is available at the end of the article
}

Iwata (2016) assume two planar faults, and Yoshida et al. (2017) model four planar faults dipping in different directions. Uchide et al. (2016) also present a model of the rupture process of the mainshock and discuss its relationship with aftershocks. Sawazaki et al. (2016) exploit high-frequency records to derive temporal variations in energy release during the period spanning nearly the entire sequence. Fukuyama and Suzuki (2016) estimate $D^{\prime \prime}$, a proxy of critical slip-weakening displacement, based on a near-fault seismogram.

Since its launch in May 2014, the Advanced Land Observing Satellite 2 (ALOS-2) of the Japan Aerospace Exploration Agency has been providing us with invaluable information on deformation of the earth's surface. ALOS-2 made observations from many tracks with different line-of-sight directions. Using the data from ALOS-2, several groups present models of coseismic deformation on faults. Himematsu and Furuya (2016) exploit pixel offsets as well as phase changes to reveal deformation. Ozawa et al. (2016) present a model with four fault segments by fitting the observed interferograms of ALOS-2. Fukahata and Hashimoto (2016) invert interferograms of ALOS-2 ScanSAR images to simultaneously estimate the slip distribution and dip angle of two fault segments. Kobayashi (2017) exploit multiple aperture interferometry as well as conventional interferometry to reveal coseismic deformation due to foreshocks. Fujiwara et al. (2016) focus on detailed features of numerous surface ruptures recognized in ALOS-2 interferograms and present their qualitative mechanism in relation to faulting and geologic structures. As in the case of the strong-motion studies, there is a variety in the geometry and number of faults, reflecting the complexity of the rupture and observed deformations. This wide variety of fault models indicates a limitation in the ability of presently available techniques for the study of earthquake sources. 
Since the target region includes the active Aso volcano, which is located along the southern boundary of the Beppu-Shimabara graben zone, the relationship between rupture process and subsurface structure is considered important. Yagi et al. (2016) and Ozawa et al. (2016) discuss the effects of stress changes due to the rupture of the mainshock on the magma reservoir of Aso volcano. Aizawa et al. (2017) analyze broadband magnetotelluric data and reveal a three-dimensional distribution of resistivity to discuss its relationship to the seismicity. Kusumoto (2016) and Matsumoto $\mathrm{N}$ et al. (2016) analyze the gravity gradient tensor and examine its relationship to the geometry of source faults. Mochizuki and Mitsui (2016) discuss the relationship between heterogeneous structure and interseismic crustal deformation. Miyakawa et al. (2016) invert gravity data to reveal a low-density body beneath the Aso caldera and discuss its possible effect on the termination of rupture. Matsumoto S et al. (2016) perform a stress tensor inversion of fault plane solutions and seismic moment tensors in central Kyushu and reveal a zone of large inelastic strain.

As mentioned above, the high intensity of ground shaking is an important issue in this earthquake sequence. Zhang et al. (2016) simulate ground motion records assuming an attenuation structure and site effect and succeed in reproducing observed ground motion. Hata et al. (2016) also try to reproduce strong ground motion, especially near the Shinkansen (bullet train system in Japan) track, with special reference to site effects. Yamanaka et al. (2016) conduct dense observation of aftershocks in heavily damaged areas and find local amplification effects in Mashiki, Nishihara and Kumamoto, but not in Minami-Aso. Chimoto et al. (2016) conduct array analysis in Mashiki and Nishihara and obtain the S-wave velocity structure, which they consider controls site amplification. On the other hand, Kawase et al. (2017) make a detailed survey of damages and reanalyze strong-motion records in the Mashiki town, attributing severe structural damages to a strong westward velocity pulse, rather than to site effects. Tsuno et al. (2017) evaluate site amplification in Kumamoto based on dense observation of microtremor and conclude that site amplification is not enough to explain observed ground motion during the mainshock. Irikura et al. (2017) examine three rupture models of the mainshock of the Kumamoto earthquake sequence and verify the effectiveness of source scaling relations for crustal earthquakes. Suzuki et al. (2017) study attenuation on strong-motion records and present a feasible method for real-time forecasting of strong motions. Nagasaka and Nozu (2017) discuss the applicability of multiple point sources to strong ground motion prediction.
During the Kumamoto earthquake sequence, many surface ruptures appeared and their origin is controversial. Tajima et al. (2017) discuss the relationship between surface ruptures found within the Aso caldera and the distribution of volcanic edifices to derive a possible link between the source fault and volcanic vents. Sugito et al. (2016) reported a detailed distribution of surface ruptures associated with the foreshock, some of which also moved during the mainshock. Shirahama et al. (2016) also compile a distribution of surface ruptures and conclude that most of them are distributed along previously identified active faults. Toda et al. (2016) examine surface ruptures aligned parallel to each other near the Mashiki town and Nishihara village and present a model of slip partitioning. Goto et al. (2017) examine subtle geomorphic features of surface ruptures using a digital elevation model in the city of Kumamoto and discuss their possible relationship to the earthquake source faults.

Seismicity change prior to a large earthquake is always an issue. Nanjo et al. (2016) present results of analyses using four different methods and detected anomalous change in seismicity. Nanjo and Yoshida (2017) discuss changes in parameters that describe seismicity between the M6.5 foreshock and M7.3 mainshock. Zhuang et al. (2017) discuss the effects of newly developed replenishments of the missing data on estimated parameters of the epidemic-type aftershock sequence (ETAS) model. Yano and Matsubara (2017) relocate hypocenters and discuss detailed features of seismicity during different periods such as 2001-2012, between the foreshock and mainshock, and after the mainshock.

A moderate earthquake hit the Yufuin city, Oita prefecture, right after the occurrence of the M7.3 mainshock. This event is considered to have been triggered by the seismic waves that radiated from the source fault of the mainshock. This phenomenon attracted the interest of many researchers. Miyazawa (2016) carefully examines the timing of triggering of the earthquake in Yufuin, exploiting a full waveform simulation of the mainshock. Enescu et al. (2016) show the activation of seismicity in volcanic areas as far away as Hokkaido as well as in nonvolcanic areas such as Noto peninsula. Yoshida (2016) re-estimates the magnitude of this triggered event using strong-motion records and GNSS data and concludes that the preliminary magnitude was underestimated. Uchide et al. (2016) also examine the magnitude of triggered events. Nakamura and Aoi (2017) estimate a focal mechanism and location of the triggered event in Yufuin.

Recent development of real-time monitoring for earthquake early warning is amazing. Applications of this newly deployed technique to the Kumamoto earthquake sequence are presented in this issue. Kawamoto et al. (2016) show the ability of the GNSS-based real-time 
analysis system (REGARD) deployed by the Geospatial Information Authority (GSI) to detect coseismic displacements and estimate size and location of the source fault. Kodera et al. (2016) examine the performance of the current seismic-based earthquake early warning system operated by the Japan Meteorological Agency (JMA) and indicate that two improved methods will be implemented in the near future.

This special issue is a compilation of preliminary works due to the limitation of available data and techniques, but gives deep insights into the generation process of this unique sequence of earthquakes. As the guest editors of this issue, we expect that these works will be a milestone for future studies of this earthquake sequence.

\section{Authors' contributions}

All authors of this article served as guest editors for this special issue. All authors read and approved the final manuscript.

\section{Author details}

${ }^{1}$ Disaster Prevention Research Institute, Kyoto University, Uji 611-0011, Kyoto, Japan. ${ }^{2}$ Institute of Geophysics, SGEES, Victoria University of Wellington, Box 600, Wellington 6140, New Zealand. ${ }^{3}$ Geological Survey of Japan, National Institute of Advanced Industrial Science and Technology, Tsukuba 305-0046, Ibaraki, Japan. ${ }^{4}$ Faculty of Science and Engineering, Doshisha University, Kyotanabe 610-0394, Kyoto, Japan.

\section{Acknowledgements}

We express sincere thankfulness to the authors who contributed to this special issue, and reviewers who evaluated the contributions and gave helpful comments and suggestions.

\section{Publisher's Note}

Springer Nature remains neutral with regard to jurisdictional claims in published maps and institutional affiliations.

Received: 10 July 2017 Accepted: 10 July 2017

Published online: 24 July 2017

\section{References}

Aizawa K, Asaue H, Koike K, Takakura S, Utsugi M, Inoue H, Yoshimura R, Yamazaki K, Komatsu S, Uyeshima M, Koyama T, Kanda W, Shiotani T, Matsushima N, Hata M, Yoshinaga T (2017) Seismicity controlled by resistivity structure: the 2016 Kumamoto earthquakes, Kyushu Island, Japan. Earth Planets Space 69:4. doi:10.1186/s40623-016-0590-2

Asano K, Iwata T (2016) Source rupture processes of the foreshock and mainshock in the 2016 Kumamoto earthquake sequence estimated from the kinematic waveform inversion of strong motion data. Earth Planets Space 68:147. doi:10.1186/s40623-016-0519-9

Chimoto K, Yamanaka H, Tsuno S, Miyake H, Yamada N (2016) Estimation of shallow S-wave velocity structure using microtremor array exploration at temporary strong motion observation stations for aftershocks of the 2016 Kumamoto earthquake. Earth Planets Space 68:206. doi:10.1186/ s40623-016-0581-3

Enescu B, Shimojo K, Opris A, Yagi Y (2016) Remote triggering of seismicity at Japanese volcanoes following the 2016 M7.3 Kumamoto earthquake. Earth Planets Space 68:165. doi:10.1186/s40623-016-0539-5

Fujiwara S, Yarai H, Kobayashi T, Morishita Y, Nakano T, Miyahara B, Nakai H, Miura Y, Ueshiba H, Kakiage Y, Une H (2016) Small-displacement linear surface ruptures of the 2016 Kumamoto earthquake sequence detected by ALOS-2 SAR interferometry. Earth Planets Space 68:160. doi:10.1186/ s40623-016-0534-x
Fukahata Y, Hashimoto M (2016) Simultaneous estimation of the dip angles and slip distribution on the faults of the 2016 Kumamoto earthquake through a weak nonlinear inversion of InSAR data. Earth Planets Space 68:204. doi:10.1186/s40623-016-0580-4

Fukuyama E, Suzuki W (2016) Near-fault deformation and Dc" during the 2016 Mw7.1 Kumamoto earthquake. Earth Planets Space 68:194. doi:10.1186/ s40623-016-0570-6

Goto H, Tsutsumi H, Toda S, Kumahara Y (2017) Geomorphic features of surface ruptures associated with the 2016 Kumamoto earthquake in and around the downtown of Kumamoto City, and implications on triggered slip along active faults. Earth Planets Space 69:26. doi:10.1186/ s40623-017-0603-9

Hata Y, Masaaki Yabe M, Kasai A, Matsuzaki H, Takahashi Y, Akiyama M (2016) Ground motion estimation for the elevated bridges of the Kyushu Shinkansen derailment caused by the foreshock of the 2016 Kumamoto earthquake based on the site-effect substitution method. Earth Planets Space 68:199. doi:10.1186/s40623-016-0573-3

Himematsu Y, Furuya M (2016) Fault source model for the 2016 Kumamoto earthquake sequence based on ALOS-2/PALSAR-2 pixel-offset data: evidence for dynamic slip partitioning. Earth Planets Space 68:169. doi:10.1186/s40623-016-0545-7 (Erratum to this article has been published in Earth, Planets and Space 68:196)

Irikura K, Miyakoshi K, Kamae K, Yoshida K, Somei K, Kurahashi S, Miyake H (2017) Applicability of source scaling relations for crustal earthquakes to estimation of the ground motions of the 2016 Kumamoto earthquake. Earth Planets Space 69:10. doi:10.1186/s40623-016-0586-y

Kawamoto S, Hiyama Y, Ohta Y, Nishimura T (2016) First result from the GEONET real-time analysis system (REGARD): the case of the 2016 Kumamoto earthquakes. Earth Planets Space 68:190. doi:10.1186/ s40623-016-0564-4

Kawase H, Matsushima S, Nagashima F, Baoyintu Nakano K (2017) The cause of heavy damage concentration in downtown Mashiki inferred from observed data and field survey of the 2016 Kumamoto earthquake. Earth Planets Space 69:3. doi:10.1186/s40623-016-0591-1

Kobayashi T (2017) Earthquake rupture properties of the 2016 Kumamoto earthquake foreshocks ( $\mathrm{M} \mathrm{6} .5$ and $\mathrm{M} \mathrm{j}$ 6.4) revealed by conventional and multiple-aperture InSAR. Earth Planets Space 69:7. doi:10.1186/ s40623-016-0594-y

Kodera Y, Saitou J, Hayashimoto N, Adachi S, Morimoto M, Nishimae Y, Hoshiba M (2016) Earthquake early warning for the 2016 Kumamoto earthquake: performance evaluation of the current system and the next-generation methods of the Japan Meteorological Agency. Earth Planets Space 68:202. doi:10.1186/s40623-016-0567-1

Kubo H, Suzuki W, Aoi S, Haruko Sekiguchi H (2016) Source rupture processes of the 2016 Kumamoto, Japan, earthquakes estimated from strong-motion waveforms. Earth Planets Space 68:161. doi:10.1186/ s40623-016-0536-8

Kusumoto S (2016) Dip distribution of Oita-Kumamoto Tectonic Line located in central Kyushu, Japan, estimated by eigenvectors of gravity gradient tensor. Earth Planets Space 68:153. doi:10.1186/s40623-016-0529-7

Matsumoto N, Hiramatsu Y, Sawada A (2016) Continuity, segmentation and faulting type of active fault zones of the 02016 Kumamoto earthquake inferred from analyses of a gravity gradient tensor. Earth Planets Space 68:167. doi:10.1186/s40623-016-0541-y (The Erratum to this article has been published in Earth, Planets and Space 69:47)

Matsumoto S, Nishimura T, Ohkura T (2016) Inelastic strain rate in the seismogenic layer of Kyushu Island, Japan. Earth Planets Space 68:207. doi:10.1186/s40623-016-0584-0

Miyakawa A, Sumita T, Okubo Y, Okuwaki R, Otsubo M, Uesawa S, Yagi Y (2016) Volcanic magma reservoir imaged as a low-density body beneath Aso volcano that terminated the 2016 Kumamoto earthquake rupture. Earth Planets Space 68:208. doi:10.1186/s40623-016-0582-2

Miyazawa M (2016) An investigation into the remote triggering of the Oita earthquake by the $2016 \mathrm{Mw} 7.0$ Kumamoto earthquake using full wavefield simulation. Earth Planets Space 68:205. doi:10.1186/ s40623-016-0585-z

Mochizuki K, Mitsui Y (2016) Crustal deformation model of the BeppuShimabara graben area, central Kyushu, Japan, based on inversion of three-component GNSS data in 2000-2010. Earth Planets Space 68:177. doi:10.1186/s40623-016-0550-x 
Nagasaka Y, Nozu A (2017) Strong ground motion simulation of the 2016 Kumamoto earthquake of April 16 using multiple point sources. Earth Planets Space 69:25. doi:10.1186/s40623-017-0612-8

Nakamura T, Aoi S (2017) Source location and mechanism analysis of an earthquake triggered by the 2016 Kumamoto, southwestern Japan, earthquake. Earth Planets Space 69:6. doi:10.1186/s40623-016-0588-9

Nanjo KZ, Yoshida A (2017) Anomalous decrease in relatively large shocks and increase in the $p$ and $b$ values preceding the April 16, 2016, M7.3 earthquake in Kumamoto, Japan. Earth Planets Space 69:13. doi:10.1186/ s40623-017-0598-2

Nanjo KZ, Izutsu J, Orihara Y, Furuse N, Togo S, Nitta H, Okada T, Tanaka R, Kamogawa M, Nagao T (2016) Seismicity prior to the 2016 Kumamoto earthquakes. Earth Planets Space 68:187. doi:10.1186/s40623-016-0558-2

Nozu A, Nagasaka Y (2017) Rupture process of the main shock of the 2016 Kumamoto earthquake with special reference to damaging ground motions: waveform inversion with empirical Green's functions. Earth Planets Space 69:22. doi:10.1186/s40623-017-0609-3

Ozawa T, Fujita E, Ueda H (2016) Crustal deformation associated with the 2016 Kumamoto Earthquake and its effect on the magma system of Aso volcano. Earth Planets Space 68:186. doi:10.1186/s40623-016-0563-5

Sawazaki K, Nakahara H, Shiomi K (2016) Preliminary estimation of highfrequency $(4-20 \mathrm{~Hz})$ energy released from the 2016 Kumamoto, Japan, earthquake sequence. Earth Planets Space 68:183. doi:10.1186/ s40623-016-0557-3

Shirahama Y, Yoshimi M, Awata Y, Maruyama T, Azuma T, Miyashita Y, Mori H, Imanishi K, Takeda N, Ochi T, Otsubo M, Asahina D, Miyakawa A (2016) Characteristics of the surface ruptures associated with the 2016 Kumamoto earthquake sequence, central Kyushu, Japan. Earth Planets Space 68:191. doi:10.1186/s40623-016-0559-1

Sugito N, Goto H, Kumahara Y, Tsutsumi H, Nakata T, Kagohara K, Matsuta N, Yoshida H (2016) Surface fault ruptures associated with the 14 April foreshock (Mj 6.5) of the 2016 Kumamoto earthquake sequence, southwest Japan. Earth Planets Space 68:170. doi:10.1186/s40623-016-0547-5

Suzuki W, Aoi S, Kunugi T, Kubo H, Morikawa N, Nakamura H, Kimura T, Fujiwara $H$ (2017) Strong motions observed by K-NET and KiK-net during the 2016 Kumamoto earthquake sequence. Earth Planets Space 69:19. doi:10.1186/ s40623-017-0604-8

Tajima Y, Hasenaka T, Torii M (2017) Effects of the 2016 Kumamoto earthquakes on the Aso volcanic edifice. Earth Planets Space 69:63. doi:10.1186/ s40623-017-0646-y
Toda S, Kaneda H, Okada S, Ishimura D, Mildon ZK (2016) Slip-partitioned surface ruptures for the Mw 7.0 16 April 2016 Kumamoto, Japan, earthquake. Earth Planets Space 68:188. doi:10.1186/s40623-016-0560-8

Tsuno S, Korenaga M, Okamoto K, Yamanaka H, Chimoto K, Matsushima T (2017) Local site effects in Kumamoto City revealed by the 2016 Kumamoto earthquake. Earth Planets Space 69:37. doi:10.1186/ s40623-017-0622-6

Uchide T, Horikawa H, Nakai M, Matsushita R, Shigematsu N, Ando R, Imanishi K (2016) The 2016 Kumamoto-Oita earthquake sequence: aftershock seismicity gap and dynamic triggering in volcanic areas. Earth Planets Space 68:180. doi:10.1186/s40623-016-0556-4

Yagi Y, Okuwaki R, Enescu B, Kasahara A, Miyakawa A, Otsubo M (2016) Rupture process of the 2016 Kumamoto earthquake in relation to the thermal structure around Aso volcano. Earth Planets Space 68:118. doi:10.1186/ s40623-016-0492-3

Yamanaka H, Chimoto K, Miyake H, Tsuno S, Yamada N (2016) Observation of earthquake ground motion due to aftershocks of the 2016 Kumamoto earthquake in damaged areas. Earth Planets Space 68:197. doi:10.1186/ s40623-016-0574-2

Yano TE, Matsubara M (2017) Effect of newly refined hypocenter locations on the seismic activity recorded during the 2016 Kumamoto Earthquake sequence. Earth Planets Space 69:74. doi:10.1186/s40623-017-0656-9

Yoshida S (2016) Earthquakes in Oita triggered by the 2016 M7.3 Kumamoto earthquake. Earth Planets Space 68:176. doi:10.1186/s40623-016-0552-8

Yoshida K, Miyakoshi K, Somei K, Irikura K (2017) Source process of the 2016 Kumamoto earthquake (Mj7.3) inferred from kinematic inversion of strong-motion records. Earth Planets Space 69:64. doi:10.1186/ s40623-017-0649-8

Zhang L, Chen G, Wu Y (2016) Jiang H (2016) Stochastic ground-motion simulations for the 2016 Kumamoto, Japan, earthquake. Earth Planets Space 68:184. doi:10.1186/s40623-016-0565-3

Zhuang J, Ogata Y, Wang T (2017) Data completeness of the Kumamoto earthquake sequence in the JMA catalog and its influence on the estimation of the ETAS parameters. Earth Planets Space 69:36. doi:10.1186/ s40623-017-0614-6

\section{Submit your manuscript to a SpringerOpen ${ }^{\odot}$ journal and benefit from:}

- Convenient online submission

- Rigorous peer review

- Open access: articles freely available online

- High visibility within the field

- Retaining the copyright to your article

Submit your next manuscript at $\boldsymbol{\nabla}$ springeropen.com 